\title{
Plant immunity inducers: from discovery to agricultural application
}

\author{
Bo Yang ${ }^{1,2}$, Sen Yang ${ }^{1,2}$, Wenyue Zheng ${ }^{1,2}$ and Yuanchao Wang ${ }^{1,2^{*}}$
}

\begin{abstract}
While conventional chemical fungicides directly eliminate pathogens, plant immunity inducers activate or prime plant immunity. In recent years, considerable progress has been made in understanding the mechanisms of immune regulation in plants. The development and application of plant immunity inducers based on the principles of plant immunity represent a new field in plant protection research. In this review, we describe the mechanisms of plant immunity inducers in terms of plant immune system activation, summarize the various classes of reported plant immunity inducers (proteins, oligosaccharides, chemicals, and lipids), and review methods for the identification or synthesis of plant immunity inducers. The current situation, new strategies, and future prospects in the development and application of plant immunity inducers are also discussed.
\end{abstract}

Keywords: Plant immunity inducer, Plant immunity, Biopesticide, Agricultural applications

\section{Introduction}

Plant diseases are responsible for substantial crop losses each year; they are threats to global agricultural sustainability and food security (Oerke and Dehne 2004). People have generally expected thorough and rapid elimination of disease-causing plant pathogens via chemical pesticide application. However, the widespread and unregulated use of chemical pesticides increases the cost of agricultural production; it also causes problems such as environmental pollution, excessive pesticide residues in agricultural products, and pathogen resistance. These problems seriously restrict the sustainable development of agriculture and directly endanger human health. To address the current food safety and environmental pollution crisis, there is an urgent need to identify new methods and technologies for plant protection that are economical, efficient, safe, and environmentally friendly. Plants normally remain healthy despite exposure to different microbes because they have evolved a multilayered immune system that can recognize all classes of

\footnotetext{
* Correspondence: wangyc@njau.edu.cn

'Department of Plant Pathology, Nanjing Agricultural University, Nanjing 210095, China

${ }^{2}$ The Key Laboratory of Plant Immunity, Nanjing Agricultural University, Nanjing 210095, China

\section{Springer}

pathogens. With advancements in science and technology, the mechanisms of plant immunity have been gradually revealed; the principles of plant immunity have been widely used in the prevention and control of crop diseases and insect pests (Dangl et al. 2013; Zipfel 2014). Biological factors that can activate plant immunity are collectively known as plant immunity inducers; these are present in many microorganisms, plants, and animals. In addition to breeding disease-resistant crops via disease resistance receptors, the improvement of crop resistance to pathogens using plant immunity inducers is an environmentally sound method for managing disease. In this review, we focus on plant immunity inducers, including their identification methods, applications, and related mechanisms. We also discuss the current status and potential future developments of plant immunity inducers.

\section{Recognition of plant immunity inducers}

In the initial stage of the interaction between pathogens and plants, pathogens must break through the physical barriers on the plant surface; they must also overcome a plant's active defense system to achieve successful colonization (Jones and Dangl 2006). During the early stage of infection, pathogens secrete some virulence factors to attack plants; plants gradually evolved membrane 
surface pattern recognition receptors to recognize the biochemically conserved pathogen-associated molecular patterns (PAMPs) of pathogens, which enable the activation of PAMP-triggered immunity (PTI). PTI is a ubiquitous but weak resistance that can temporarily prevent infection by most pathogens (Jones and Dangl 2006). In turn, pathogens have evolved diverse virulence factors (i.e., effectors) that can be delivered into host cells to interfere with PTI and dampen basal defenses (Jones and Dangl 2006; Wang et al. 2019b). In response, plants have developed an additional layer of defense that enables them to intercept pathogen effectors, leading to effectortriggered immunity. This layer of plant defense is driven by a family of polymorphic intracellular nucleotidebinding/leucine-rich repeat receptors. However, adaptive plant pathogens have gained the ability to overcome effector-triggered immunity by effector variation or the secretion of new effectors (Jones and Dangl 2006). Compared to PTI, effector-triggered immunity leads to stronger resistance, usually accompanied by the hypersensitive response, a form of programmed cell death at the site of infection. However, the large-scale use of a single diseaseresistant variety in the field will increase selection pressure among pathogens, thus accelerating their evolution; such changes are not conducive to the long-term prevention and control of plant diseases. The induced resistance of plants makes full use of the potential ability for plants themselves to prevent disease; it induces a basic immune response by regulating plant defense and metabolic systems to delay or mitigate disease occurrence and development.

Plant pattern recognition receptors that recognize PAMPs include receptor-like kinases (RLKs) and receptor-like proteins (RLPs) (Shiu and Bleecker 2003; Shiu et al. 2004). RLKs are located on the plasma membrane and contain an extracellular ligand binding domain, a transmembrane domain, and intracellular protein kinase domain. By contrast, RLPs only contain extracellular and transmembrane domains; they lack intracellular kinase domains. Thus, RLPs must bind to other intracellular coreceptor kinases to transmit downstream signals (Boutrot and Zipfel 2017). Although many plant immunity inducers and their corresponding recognition receptors have been identified, the induction of plant immunity by most elicitors remains poorly understood. The best-characterized PAMPs are bacterial flagellin (recognized by plant flagellin-sensing 2 [FLS2]) and bacterial elongation factor $\mathrm{Tu}$ (EF-Tu; recognized by the LRR-RLK EF-Tu receptor) (Gomez-Gomez and Boller 2000; Zipfel et al. 2006). Flagellin is a structural protein of a bacterial flagellum, which extends from the cell surface and allows bacteria to be motile. Flg22, a conserved 22-amino acid epitope of the $\mathrm{N}$ terminus of flagellin, is sufficient to activate an immune response. However, flg22 is buried in the flagellin polymer structure, such that it cannot bind to FLS2 (Fliegmann and Felix 2016). A recent study revealed that plants use glycosidase to facilitate the release of flg22 from invading bacteria (Buscaill et al. 2019). FLS2 homologous genes have been found in all higher plants with known genomic information. Proteins homologous to FLS2 in tobacco, rice, and tomato recognize bacterial flagellin. These results indicate that plant FLS2 proteins function as evolutionarily conserved and ancient receptors to recognize flagellin (Felix et al. 1999; Gomez-Gomez and Boller 2000).

The recognition of plant immunity inducers by plant receptors is only the beginning of the immune response. Pattern recognition receptors must work in conjunction with other plasma membrane proteins to transmit immune signals downstream through the corresponding signal transduction pathway, enabling plants to perform additional immune response functions (Liang and Zhou 2018). BRI1-associated receptor kinase 1 (BAK1) is a coreceptor protein that participates in various signaling pathways; it is involved in PTI signaling mediated by multiple PAMPs receptor complexes (Chinchilla et al. 2009). After the activation of plant pattern recognition receptors, the signal is usually transmitted downstream by protein phosphorylation; it causes disease-related immune responses such as downstream $\mathrm{Ca}^{2+}$ signal inflow, reactive oxygen accumulation, callose accumulation, stomatal closure, and salicylic acid production (Liang and Zhou 2018; Tang et al. 2017; Zhou and Zhang 2020).

\section{Major classes of plant immunity inducers}

Plant immunity inducers can be derived from animals, plants, microbes or their metabolites, active molecules produced during interactions between plants and microbes, or natural/synthetic compounds. According to their chemical properties, plant immunity inducers can be classified into proteins, oligosaccharides, glycopeptides, lipids, lipopeptides, small molecule metabolites, and chemical compounds (Boutrot and Zipfel 2017; Schwessinger and Ronald 2012). In this review, we have listed a wide array of plant immunity inducers that have been shown to induce PTI-like responses in plants (Table 1). The identification of these components has accumulated considerable resources for the development of plant immune-induced pesticides.

\section{Plant immunity-inducing proteins}

In recent years, many plant immunity-inducing proteins, such as flagellin (Felix et al. 1999), harpin (Dong et al. 1999), nepl-like protein (Oome et al. 2014), xylanase (Fuchs et al. 1989), elicitin (Ricci et al. 1989), cellulose (Ma et al. 2015a), RNAse (Yang et al. 2021), and aldose 1-epimerase (Xu et al. 2021) have been identified in bacteria, fungi, oomycetes, viruses, and plants (Table 1). Here, we highlight several recently discovered plant 
Table 1 The major classes of plant immune inducers

\begin{tabular}{|c|c|c|c|}
\hline Attributes & Names & Origin & Refs. \\
\hline \multirow[t]{44}{*}{ Proteins } & Harpin & Pseudomonas syringae & (Dong et al. 1999) \\
\hline & Siderophore & Pseudomonas fluorescens & (Leeman et al. 1996) \\
\hline & Flagellin & Pseudomonas syringae & (Felix et al. 1999) \\
\hline & Nep1-like protein & Bacillus halodurans & (Oome et al. 2014) \\
\hline & AMEP412 & Bacillus subtilis & (Shen et al. 2019) \\
\hline & SodM & Escherichia coli & (Watt et al. 2006) \\
\hline & EF-Tu & Escherichia coli & (Kunze et al. 2004) \\
\hline & PGN & Staphylococcus aureus & (Gust et al. 2007) \\
\hline & CSP & Staphylococcus aureus & (Felix and Boller 2003) \\
\hline & PeBL1 & Brevibacillus laterosporus & (Wang et al. 2015) \\
\hline & $\mathrm{EG} 1(\mathrm{GH} 45)$ & Rhizoctonia solani & (Ma et al. 2015a) \\
\hline & EIF & Trichoderma viride & (Fuchs et al. 1989) \\
\hline & Nip1 & Rhynchosporium commune & (Rohe et al. 1995) \\
\hline & MgSM1 & Magnaporthe grisea & (Yang et al. 2009) \\
\hline & PemG1 & Magnaporthe oryzae & (Peng et al. 2011) \\
\hline & Ave1 & Verticillium dahliae & (de Jonge et al. 2012) \\
\hline & PevD1 & Verticillium dahliae & (Wang et al. 2012a) \\
\hline & PebC1 & Botrytis cinerea & (Zhang et al. 2014c) \\
\hline & $\mathrm{BcGs1}(\mathrm{GH} 15)$ & Botrytis cinerea & (Zhang et al. 2015) \\
\hline & BCIEB1 & Botrytis cinerea & (Frias et al. 2016) \\
\hline & BcPGs (GH28) & Botrytis cinerea & (ten Have et al. 1998) \\
\hline & T4BCPG1 & Botrytis cinerea & (Poinssot et al. 2003; Zhang et al. 2014b) \\
\hline & Hrip & Alternaria tenuissima & (Kulye et al. 2012) \\
\hline & AsES & Acremonium strictum & (Chalfoun et al. 2013) \\
\hline & SsCut & Sclerotinia sclerotiorum & (Zhang et al. 2014a) \\
\hline & Cyclodipeptides & Eupenicillium brefeldianum & (Chen et al. 2015) \\
\hline & CS20EP & Fusarium oxysporum & (Shcherbakova et al. 2016) \\
\hline & RALF & Fusarium oxysporum, Arabidopsis & (Pearce et al. 2001; Thynne et al. 2017) \\
\hline & Six4 & Fusarium oxysporum & (Houterman et al. 2008) \\
\hline & Six 1 & Fusarium oxysporum & (Rep et al. 2004) \\
\hline & SnTox1 & Stagonospora nodorum & (Liu et al. 2012b) \\
\hline & PB90 & Phytophthora boehmeriae & (Wang et al. 2003) \\
\hline & Elicitin & Phytophthora capsici & (Ricci et al. 1989) \\
\hline & OPEL (GH16) & Phytophthora parasitica & (Chang et al. 2015) \\
\hline & GP42 & Phytophthora sojae & (Nurnberger et al. 1994) \\
\hline & AEP1 & Phytophthora sojae & (Xu et al. 2021) \\
\hline & PC2 & Phytophthora infestans & (Wang et al. 2021) \\
\hline & SCR96 & Phytophthora cactorum & (Chen et al. 2016) \\
\hline & CBEL & Phytophthora parasitica & (Gaulin et al. 2006) \\
\hline & PCF & Phytophthora cactorum & (Orsomando et al. 2001) \\
\hline & XEG1 & Phytophthora sojae & (Ma et al. 2015b) \\
\hline & $\mathrm{GH} 17$ & Cladosporium fulvum & (Ökmen et al. 2019) \\
\hline & NLP & Phytophthora parasitica & (Böhm et al. 2014) \\
\hline & TaMCA4 & Puccinia striiformis f. sp. tritici & (Wang et al., 2012b) \\
\hline
\end{tabular}


Table 1 The major classes of plant immune inducers (Continued)

\begin{tabular}{|c|c|c|c|}
\hline Attributes & Names & Origin & Refs. \\
\hline & Coat protein & Tobacco mosaic virus & (Allan et al. 2001) \\
\hline & Gr-VAP1 & Heterodera rostochiensis & (Lozano-Torres et al. 2012) \\
\hline & VmE02 & Valsa mali & (Nie et al. 2019) \\
\hline & VdCP1 & Verticillium dahliae & (Zhang et al. 2017) \\
\hline & VdPEL1 & Verticillium dahliae & (Yang et al. 2018) \\
\hline & AGLIP1 & Rhizoctonia solani & (Li et al. 2019) \\
\hline & BAR11 & Saccharothrix yanglingensis & (Zhang et al. 2018b) \\
\hline & CfPDIP1 & Colletotrichum falcatum & (Ashwin et al. 2018) \\
\hline & $\mathrm{Fg} 12$ & Fusarium graminearum & (Yang et al. 2021) \\
\hline & Systemin & Tomato & (Pearce et al. 1991) \\
\hline & ATP synthase & Maize & (Schmelz et al. 2006) \\
\hline \multirow[t]{4}{*}{ Peptide } & Phytosulfokine & Tomato & (Zhang et al. 2018a) \\
\hline & AtPep1 & Arabidopsis & (Huffaker et al. 2006) \\
\hline & PIPs & Arabidopsis & (Hou et al. 2014) \\
\hline & GmPeps & Soybean & $\begin{array}{l}\text { (Lee et al. 2018; Pearce et al. 2010; } \\
\text { Yamaguchi et al. 2011) }\end{array}$ \\
\hline \multirow[t]{11}{*}{ Carbohydrates } & Exopolysaccharides & Xanthomonas campestris pv. vesicatoria & (Romeiro and Kimura 1997) \\
\hline & Chitin & Agaricus bisporus & (Kaku et al. 2006) \\
\hline & Oligochitosan & Fusarium solani & (Cabrera et al. 2006) \\
\hline & Heptaglucoside & Phytophthora sojae & (Sharp et al. 1984) \\
\hline & Xyloglucan & Rubus fruticosus & (Joseleau et al. 1992) \\
\hline & D-allose & Oryza sativa & (Kano et al. 2010) \\
\hline & Galactinol & Tobacco & (Kim et al. 2008) \\
\hline & Trehalose & Arabidopsis & (Reignault et al. 2001) \\
\hline & Laminarin & Arabidopsis & (Ménard et al. 2004) \\
\hline & Lichenan & Tobacco & (Stübler and Buchenauer 1996) \\
\hline & Mannan oligosaccharides & Carob & (Zang et al. 2019) \\
\hline \multirow[t]{12}{*}{ Lipids/Lipopeptides } & Lipopolysaccharides & Staphylococcus aureus & (Dow et al. 2000) \\
\hline & $\mathrm{N}$-acyl-homoserine lactones & Serratia liquefaciens & (Schuhegger et al. 2006) \\
\hline & Fatty acid amides & Spodoptera exigua & (Alborn et al. 1997) \\
\hline & Surfactin & Bacillus amyloliquefaciens & (Rahman et al. 2015) \\
\hline & Ergosterol & Cladosporium fulvum & (Granado et al. 1995) \\
\hline & Fengycin & Bacillus amyloliquefaciens & (Farzand et al. 2019) \\
\hline & Iturin & Bacillus amyloliquefaciens & (Han et al. 2015) \\
\hline & Lokisin & Pseudomonas sp. COR10 & (Omoboye et al. 2019) \\
\hline & Eicosapentaenoic acid & Phytophthora infestans & (Bostock et al. 1981) \\
\hline & Arachidonic acid & Phytophthora infestans & (Savchenko et al. 2010) \\
\hline & Cerebroside & Magnaporthe oryzae & (Koga et al. 1998) \\
\hline & Rhamnolipids & Pseudomonas aeruginosa & (Crouzet et al. 2020; Sanchez et al. 2012) \\
\hline \multirow[t]{2}{*}{ Nucleotides } & Extracellular ATP & Arabidopsis & (Clark et al. 2011; Tanaka et al. 2014) \\
\hline & Extracellular pyridine nucleotides & & (Wang et al. 2019a) \\
\hline \multirow[t]{3}{*}{ Chemical } & DL- $\beta$-aminobutyric acid & & (Hong et al. 1999) \\
\hline & Benzothiadiazole & & (Oostendorp et al. 2001) \\
\hline & 2,6-dichloro isonicotinic acid & & (Qian et al. 2006) \\
\hline
\end{tabular}


Table 1 The major classes of plant immune inducers (Continued)

\begin{tabular}{|c|c|c|c|}
\hline Attributes & Names & Origin & Refs. \\
\hline & Isotianil & & (Kumar et al. 2018) \\
\hline & Methiadinil & & (Wang et al. 2017) \\
\hline & Probenazole & & (Yoshioka et al. 2001) \\
\hline & Dufulin & & (Li and Song 2017) \\
\hline & 4-fluorophenoxyacetic acid & & (Wang et al. 2020) \\
\hline & 3-pentanol & Bacillus amyloliquefaciens & (Choi et al. 2014a) \\
\hline & Pipecolic acid & Plants & (Návarová et al. 2012) \\
\hline & 2,4-diacetyl phloroglucinol & Pseudomonas fluorescens & (Chae et al. 2020) \\
\hline & 2,3-butanediol & Pseudomonas chlororaphis & (Kong et al. 2018) \\
\hline & Hexadecane & Paenibacillus polymyxa & \\
\hline & Tridecane & Paenibacillus polymyxa & (Lee et al. 2012) \\
\hline
\end{tabular}

immunity-inducing proteins. PsXEG1 is an apoplastic xyloglucan-specific endoglucanase that is secreted by soybean root rot pathogen Phytophthora sojae; it belongs to the glycoside hydrolase GH12 family (Ma et al. 2015b). It can promote $P$. sojae infection via plant cell wall degradation. Furthermore, PsXEG1-like GH12 proteins are widely distributed in Phytophthora, many pathogenic fungi, and bacteria. PsXEG1 can induce multiple plant immune responses, including oxidative burst, callose accumulation, robust expression of diseaseresistant genes, and the hypersensitive response in plants (Ma et al. 2015b; Ma et al. 2017). Notably, PsXEG1 induces immune responses in soybean plant, which is the host plant of P. sojae; it also elicits cell death in nonhost plants such as tobacco, tomato, and pepper, indicating that plants recognize PsXEG1 using a conserved mechanism. The recognition of XEG1 in plants depends on the RLP kinase protein BAK1, which is a co-receptor that transmits immune signals via cooperation with other receptor proteins ( $\mathrm{Ma}$ et al. 2015b). A highthroughput LRR receptor-like gene silencing library was established in Nicotiana benthamiana, which can efficiently silence 386 LRR receptor-like genes. NbRXEG1, a receptor-like protein that is responsible for the recognition of PsXEG1, was successfully identified via screening of this library (Wang et al. 2018). NbRXEG1 can specifically bind to PsXEG1, thereby activating the corresponding immune pathway (Wang et al. 2018). Fg12, a ribonuclease secreted by Fusarium graminearum, induces cell death in $N$. benthamiana in a light-dependent manner; F. graminearum pathogenesis depends on the ribonuclease activity of Fg12 (Yang et al. 2021). P. sojae-secreted aldose 1epimerase triggers cell death in plants such as tobacco, tomato, potato, eggplant, pepper, and Arabidopsis. The enzymatic activity of aldose 1-epimerase is dispensable for its cell death-inducing activity, while aldose 1-epimerasemediated immune signaling in $N$. benthamiana requires BAK1 (Xu et al. 2021). Many other microbe-derived plant immunity-inducing proteins (e.g., glycosyl hydrolase GH17 protein, lipase, and some proteins without known functional domains) also exhibit robust plant immunityinducing activity.

In addition to microbe-derived plant immunity inducers, some plant-derived elicitors activate plant defense responses. For instance, a universally conserved plantderived elicitor is Pep1, a conserved epitope derived from the C terminus of PROPEP1 (Huffaker et al. 2006). Pep1 is recognized on the cell surface by the PEPRs, leading to the induction of immune responses (Krol et al. 2010; Yamaguchi et al. 2010). One study has provided excellent proof that metacaspase MC4 is responsible for PROPEP1 cleavage and the release of Pep1 (Hander et al. 2019). Other plant-derived elicitors, such as GmPep914 and GmSubPep (two peptides identified in soybean) can effectively induce plant resistance to different pathogens (Pearce et al. 2010; Yamaguchi et al. 2011).

\section{Plant immunity-inducing carbohydrates}

There are abundant plant immunity-inducing carbohydrates in nature. Most are derived from the shell or cell wall of animals, plants, or microbes; they include exopolysaccharides, chitin, xyloglucan, and oligochitosan (Table 1) (Cabrera et al. 2006; Kaku et al. 2006; Romeiro and Kimura 1997; Sharp et al. 1984). Mannan oligosaccharide, which is hydrolyzed from locust bean gum, significantly enhances the generation of intracellular $\mathrm{Ca}^{2+}$ and reactive oxygen species, as well as the accumulation of four phytoalexins (Zang et al. 2019). Treatment with mannan oligosaccharide conferred resistance in rice and tobacco against Xanthomonas oryzae and Phytophthora nicotianae. Laminarin is a water-soluble $\beta$-1,3-glucan that can induce defense responses in plants such as tobacco, Arabidopsis, and rice (Klarzynski et al. 2000). It can induce immune pathways that rely on the salicylic acid signaling pathway, including the accumulation of phytoalexins and expression of various disease-related 
proteins (Klarzynski et al. 2000). Trehalose is a nonreducing disaccharide widely distributed in many species. The treatment of wheat with trehalose significantly increases wheat resistance to powdery mildew by increasing the enzymatic activity of phenylalanine ammonia lyase and peroxidase, which are related to the wheat defense response (Reignault et al. 2001). Chitin, a major component in the cell wall of filamentous fungi, induces defense responses in various plants. OsCEBiP and AtLYK5, two receptors identified in rice and Arabidopsis thaliana, respectively, have been described as receptors that directly bind to chitin (Hayafune et al., 2014; Cao et al., 2014). CERK1, a receptor-like kinase containing a lysozyme structure, also has an important role in chitin recognition (Cao et al., 2014; Petutschnig et al. 2010). In addition, the receptor-like proteins AtLYM2, OsLYP4, and OsLYP6 are required for responses to peptidoglycan and chitin (Faulkner et al. 2013; Liu et al. 2012a).

\section{Plant immunity-inducing lipids}

Currently, the known plant immunity-inducing lipids mainly include lipopolysaccharide, ergosterol, eicosapentaenoic acid, and arachidonic acid (Bostock et al. 1981; Dow et al. 2000; Granado et al. 1995; Savchenko et al. 2010). Lipopolysaccharide is a component of the cell wall of Gram-negative bacteria; it is essential for bacterial infection (Dow et al. 2000). It can also be recognized by various plants and induce plant immune responses. Medium-chain 3-hydroxy fatty acids, widely present in Gram-negative bacteria, are reportedly recognized by a lectin S-domain receptor kinase LORE (Kutschera et al., 2019). Ergosterol, a component extracted from fungus, induces the extracellular alkalization of tomato cells and activates immune responses in tomatoes, requiring only a low concentration (Granado et al. 1995). Similarly, arachidonic acid and eicosapentaenoic acid from Phytophthora infestans can activate immune responses in potato (Bostock et al. 1981; Savchenko et al. 2010). Fatty acid amides, isolated from the oral secretions of Spodoptera exigua caterpillar larvae, induce corn seedlings to emit volatile compounds that attract natural enemies of the caterpillars (Alborn et al. 1997).

\section{Plant immunity-inducing chemical compounds}

Chemical compounds such as benzothiadiazole, 2,6dichloro isonicotinic acid, probenazole, and dufulin are elicitors that activate plant immunity. For example, benzothiadiazole induces plant resistance to numerous diseases, consistent with its resemblance to salicylic acid (Thakur and Sohal 2013). DL- $\beta$-aminobutyric acid can induce local and systemic resistance to Colletotrichum coccodes in pepper plants (Hong et al. 1999). Isotianil, which was identified by Bayer AG and Sumitomo
Chemical Co., Ltd., induces the expression of plant pathogenesis-related genes; it can efficiently activate rice resistance to rice blast disease (Kumar et al. 2018). Dufulin enhances defense enzyme activity, increases the chlorophyll content in tobacco leaves, and prevents tobacco viral diseases ( $\mathrm{Li}$ and Song 2017). Recently, 4fluorophenoxyacetic acid has been shown to suppress white-backed planthopper Sogatella furcifera populations and increase crop yields in the field (Wang et al. 2020). 4-Fluorophenoxyacetic acid modulates the production of peroxidases, $\mathrm{H}_{2} \mathrm{O}_{2}$, and flavonoids; it directly triggers the formation of flavonoid polymers, thereby increasing the resistance of cereals to piercing-sucking insect pests (Wang et al. 2020).

\section{Other types of plant immunity inducer}

In addition to the inducers described above, substances such as extracellular ATP and cerebroside can activate plant immunity. For example, at a particular concentration, extracellular ATP from plants can induce stomata closure. The receptor-like kinase DORN1 is the receptor of extracellular ATP in plants. The recognition of extracellular ATP by DORN1 induces immune responses such as calcium burst and mitogen-activated protein kinase activation in plants (Choi et al. 2014b).

\section{Strategies for identification or chemosynthesis of plant immunity inducers}

Biochemical approaches to identify plant immunity inducers The most commonly used and most effective method for identification of plant immunity inducers is isolation and purification from the culture extracts of microorganisms via biochemical approaches. Single components are separated from cultures by ion exchange chromatography and high-performance liquid chromatography; the compositions of those single components are then identified by mass spectrometry. Many plant immune elicitors have been successfully identified by this method, such as flagellin from Pseudomonas syringae (Felix et al. 1999) and glycosyl hydrolase PsXEG1 from P. sojae (Ma et al. 2015b). In addition, nuclear magnetic resonance spectroscopy and fast atom bombardment analysis have been employed to identify cerebroside from Magnaporthe oryzae (Koga et al. 1998). Finally, the use of known receptor proteins as molecular bait is a promising approach to identify plant immunity inducers that can specifically bind to those receptor proteins.

\section{Sequence analysis to identify plant immunity inducers}

Comparison of the sequence similarity of existing plant immunity inducers among species is an effective method to identify new plant immunity inducers. For example, necrosis- and ethylene-inducing peptide (NLP) protein was initially identified in the pathogenic fungus 
Fusarium oxysporum (Bailey 1995). Through similarity comparison, multiple NLP (Nep1-like) proteins were identified in bacteria, fungi, and oomycetes (Oome et al. 2014; Qutob et al. 2002). Recent studies have shown that the 24 amino acids (nlp24) conserved in the NLP protein are sufficient to induce immune responses in plants; the NLP receptor RLP23 has also been identified in A. thaliana (Albert et al. 2015). Many other variants of plant immunity inducers have been identified through sequence homology analysis, such as oomycete elicitin and bacterial flagellin (Derevnina et al. 2016).

\section{Chemosynthesis of plant immunity inducers}

Advances in combinatorial chemistry and the development of high-throughput screening systems have enabled scientists to conduct comprehensive assays for the identification of synthetic plant immunity inducers. Simple chemical derivation of known plant immunity inducers is an efficient method to design more potent immune elicitors (Zhou and Wang 2018). The combination of a known synthetic plant immunity inducer with another functional compound is also effective for the generation of bifunctional product. For example, the combination of 3,4-dichloroisothiazoles with fungicidal strobilurins produced a new synthetic compound with good fungicide activities (Chen et al. 2017). Moreover, the computer-aided design compound design strategy has been utilized for pesticide discovery and property analysis. Thus, applications of computer-aided design can generate new plant immunity inducers.

\section{Applications of plant immunity inducers}

In recent years, the development and generation of plant immunity inducers have been conducted based on known plant immunity elicitors. A notable example is the harpin protein isolated from the plant pathogen Erwinia amylovora by Cornell University and Eden Biotechnology (Wei et al. 1992). The harpin protein has a unique immune-activating function; it has been developed into a protein biological pesticide: Messenger. After years of application, Messenger has become a worldrenowned immunity inducer with protective activity against numerous plant diseases. This achievement has won the "Presidential Green Chemistry Challenge Award" issued by the Environmental Protection Agency. It has been widely used in the growth of fruit, tobacco, and vegetables. In addition, researchers from the Institute of Plant Protection of the Chinese Academy of Agricultural Sciences have isolated and purified plant immunity-inducing proteins such as PeaT1 and Hrip1 from Alternaria tenuissima and other pathogenic fungi (Kulye et al. 2012). ATaiLing, which mainly consists of plant immunity-inducing proteins and oligosaccharides, was approved for pesticide application in 2014. Field trials showed that its prevention and control effects against crop virus disease were greater than $70 \%$, and the crop yield was increased by more than $10 \%$; it received considerable praise from farmers after release to the broader market (Qiu 2016). Researchers from China Agricultural University identified the immune-activating protein VdAL in Verticillium dahlia; they showed that the treatment of cucumber seedlings with VdAL led to significant resistance enhancement and improved the storage quality of cucumber commercial seedlings (Sun et al. 2016). ZhiNengCong, an extract of the fungal endophyte Paecilomyces variotii, has been widely used in China (Lu et al. 2019). ZhiNengCong functions as an elicitor to both induce plant resistance and promote crop growth (Lu et al. 2019).

Many research groups have made considerable progress in the development of plant immunity-inducing oligosaccharides. For example, the Dalian Institute of Chemical Physics, Chinese Academy of Sciences has made important breakthroughs in identifying applications of oligosaccharides. In particular, chitosan oligosaccharides have been used as raw materials to develop plant immunityinducing oligosaccharides; these oligosaccharides received multiple approvals for pesticide application and provided considerable improvements in crop yield and quality (Qiu 2016). In addition, Korea Ukseung Chemical Co., Ltd. developed a chitosan product, with an active ingredient of chitosan oligosaccharide, which is derived from the shells of shrimp, crab, and other organisms. The treatment of crop seeds with this agent significantly prevented disease and increased yields. Chitosan-oligosaccharide biologics have been certified as environmentally friendly crop production active agents by the Ministry of Agriculture and Forestry of Korea. Moreover, oligochitosan can stimulate defense responses in rice leaves, increasing the production of phenolic secondary metabolites to enhance resistance against rice blast disease (Agrawal et al. 2002). The treatment of wheat with oligochitosan promoted resistance to Bipolaris sorokiniana (Burkhanova et al. 2007). In addition to applications in crop plants, oligochitosan has been shown to induce tobacco resistance to Phytophthora parasitica and potato resistance to Phytophthora infestans (Falcón et al. 2008; Ozeretskovskaya et al. 2006). Researchers have also developed various plant immunity-inducing chemical compounds, such as dufulin, which was generated by a research team from Guizhou University. Isotianil, an isothiazole-based synthetic plant immunity inducer, has been widely used in Japan to control rice disease.

\section{Promising new strategies for the utilization of plant immunity inducers}

After the identification of plant immunity inducers from plants or microorganisms, large-scale utilization remains an important challenge. Ectopic expression of the genes 
that encode elicitors in plants is also an effective strategy. For instance, the overexpression of harpin-encoding genes confers enhanced resistance to pathogens in several transgenic plants (e.g., soybean, rice, tobacco, and sugar beet) (Du et al. 2018; Li et al. 2012; Pavli et al. 2011). In addition to using transgenic plants, engineered bacteria are often used to produce plant immunity inducers; for example, harpin protein was industrially produced in a genetically engineered strain of Escherichia coli (Bauer et al. 1997; Wei et al. 1992). However, the target proteins must be released from bacterial cells by sonication or high pressure; the protein purification step is expensive. In addition, during the production and purification of proteins in E. coli, there are problems such as inefficient gene expression, protein inclusion body formation, and bacterial toxin production. Thus, microbes that secrete proteins directly into the fermentation broth offer major advantages for downstream production processing. Bacillus species are excellent microorganisms for use in secreted protein production. Bacillus subtilis is one of the best-characterized Grampositive bacteria; it has been widely used because of its high product yields, its complete lack of toxic byproducts, and its excellent fermentation properties (van Dijl and Hecker 2013). For example, B. subtilis-mediated expression of the $\mathrm{HpaG}_{\text {Xooc }}$ protein, which is a component of the harpin protein from $X$. oryzae pv. oryzicola, elicits the hypersensitive response and enhances growth in tobacco (Wu et al. 2009). Moreover, B. subtilis is classified as "generally recognized as safe" by the US Food and Drug Administration; several B. subtilis strains promote plant growth and increase plant resistance. Recently, a new strategy was proposed to manage plant diseases by combining two effective methods: use of the plant Pep elicitor to enhance crop resistance to plantparasitic nematodes and use of $B$. subtilis for efficient delivery of these elicitors (Hiltl and Siddique 2020; Zhang and Gleason 2020). This strategy will provide new avenues for the combined application of plant immunity inducers and beneficial microorganisms to protect plant health.

\section{Prospects for the development of plant immunity inducers}

The development of plant immunity inducers is a new field of plant immunity engineering technology. This popular new field enables scientists to scientifically control pests and diseases based on plant immunity theory, supporting biopesticide generation; it is expected to become a new strategic industry with extensive development prospects (Qiu et al. 2017). Compared to chemical pesticides, plant immunity inducers have many advantages, such as their exceptionally low dosage, lack of damaging effects for humans and animals, lack of adverse effects on the environment, ability to induce substantial disease resistance, induction of long-term and broad-spectrum plant resistance, low risk for microbial resistance, and ability to reduce the use of chemical pesticides-this reduction can aid in environmental protection efforts. In recent years, the Chinese government has increasingly focused on environmental protection; it has prioritized the construction of ecological civilization. The government vigorously promotes the reduction of pesticides and fertilizers; it also advocates for increased efficiency and the active exploration of efficient, safe, and environmentally friendly modern agricultural development. The identification, development, and application of plant immunity inducers meet the strategic needs of national development; it has important academic value and can serve agricultural production, facilitating important contributions to ensure widespread food safety and sustainable agriculture development.

Regarding the research and application of future plant immunity inducers, there are several important considerations. First, a system must be constructed for the screening, functional analysis, and evaluation of the activities of plant immunity inducers, which must be systematically identified from different sources. Second, there is a need to investigate plant recognition receptors, key recognition sites, and signaling pathways of plant immunity inducers to identify the corresponding mechanisms. The identification of principal compounds that elicit resistance is an important aspect that must be considered. Third, new technologies and processes are needed for the large-scale production of plant immunity inducers, thereby reducing the cost of their industrialization. Fourth, the rational combination of plant immunity inducers and chemical pesticides, beneficial microorganisms, or fertilizer is needed for synergistic enhancement of plant resistance and production. Finally, synthetic compounds should be designed based on the structures of plant receptors and their key sites for recognition; these efforts will promote the generation of plant immunity inducers.

\section{Acknowledgments \\ We thank Yuyin Wang and Kaixin Dai for critical reading of the manuscript Because of space limitations, we apologize to our colleagues whose important works were not cited in this review.}

Adherence to national and international regulations Not applicable.

\section{Authors' contributions}

This work was supervised by Yuanchao Wang. The original draft was prepared by Bo Yang, Sen Yang, and Wenyue Zheng; it was revised by Yuanchao Wang. All authors read and approved the final manuscript.

\section{Funding}

This work was supported by the National Natural Science Foundation of China (31721004, 32001882), the Natural Science Foundation of Jiangsu Province (BK20190520), the China Post-doctoral Science Foundation (2018 
M640496), and the National Postdoctoral Program for Innovative Talents (BX20180142).

\section{Availability of data and materials}

Not applicable.

\section{Declarations}

\section{Ethics approval and consent to participate}

Not applicable.

\section{Consent for publication}

Not applicable.

\section{Competing interests}

Author Yuanchao Wang is a member of the Editorial Board of this journal but was not involved in the journal's review of, or decisions related to, this manuscript.

\section{Received: 11 October 2021 Accepted: 13 December 2021}

Published online: 10 January 2022

\section{References}

Agrawal GK, Rakwal R, Tamogami S, Yonekura M, Kubo A, Saji H (2002) Chitosan activates defense/stress response (s) in the leaves of Oryza sativa seedlings. Plant Physiol Biochem 40(12):1061-1069. https://doi.org/10.1016/S0981-942 8(02)01471-7

Albert I, Bohm H, Albert M, Feiler CE, Imkampe J, Wallmeroth N, Brancato C, Raaymakers TM, Oome S, Zhang HQ, Krol E, Grefen C, Gust AA, Chai JJ, Hedrich R, Van den Ackerveken G, Nurnberger T (2015) An RLP23-SOBIR1BAK1 complex mediates NLP-triggered immunity. Nat Plants 1:15140. https://doi.org/10.1038/Nplants.2015.140

Alborn H, Turlings T, Jones TH, Stenhagen G, Loughrin J, Tumlinson J (1997) An elicitor of plant volatiles from beet armyworm oral secretion. Science 276 945-949

Allan AC, Lapidot M, Culver JN, Fluhr R (2001) An early tobacco mosaic virusinduced oxidative burst in tobacco indicates extracellular perception of the virus coat protein. Plant Physiol 126:97-108. https://doi.org/10.1104/Pp.126.1.97

Ashwin N, Barnabas L, Sundar AR, Malathi P, Viswanathan R, Masi A, Agrawal GK, Rakwal R (2018) CfPDIP1, a novel secreted protein of Colletotrichum falcatum, elicits defense responses in sugarcane and triggers hypersensitive response in tobacco. Appl Microbiol Biotechnol 102:6001-6021

Bailey BA (1995) Purification of a protein from culture filtrates of fusarium oxysporum that induces ethylene and necrosis in leaves of Erythroxylum coca. Phytopathology 85:1250-1255. https://doi.org/10.1094/Phyto-85-1250

Bauer DW, Zumoff CH, Theisen TM, Bogdanove AJ, Beer SV (1997) Optimized production of Erwinia amylovora harpin and its use to control plant disease and enhance plant growth. Phytopathology 87:S7-S7

Böhm H, Albert I, Oome S, Raaymakers TM, Van den Ackerveken G, Nürnberger T (2014) A conserved peptide pattern from a widespread microbial virulence factor triggers pattern-induced immunity in Arabidopsis. PLoS Pathog. 10.

Bostock RM, Kuc JA, Laine RA (1981) Eicosapentaenoic and arachidonic acids from Phytophthora infestans elicit fungitoxic sesquiterpenes in the potato. Science 212:67-69

Boutrot F, Zipfel C (2017) Function, discovery, and exploitation of plant pattern recognition receptors for broad-spectrum disease resistance. Annu Rev Phytopathol 55:257-286. https://doi.org/10.1146/annurev-phyto-080614-12 0106

Burkhanova G, Yarullina L, Maksimov I (2007) The control of wheat defense responses during infection with Bipolaris sorokiniana by chitooligosaccharides. Russ J Plant Physiol 54(1):104-110. https://doi.org/1 $0.1134 /$ S1021443707010153

Buscaill P, Chandrasekar B, Sanguankiattichai N, Kourelis J, Kaschani F, Thomas EL, Morimoto K, Kaiser M, Preston GM, Ichinose Y, van der Hoorn RAL (2019) Glycosidase and glycan polymorphism control hydrolytic release of immunogenic flagellin peptides. Science 364:6436. https://doi.org/10.1126/ science.aav0748

Cabrera JC, Messiaen J, Cambier P, Van Cutsem P (2006) Size, acetylation and concentration of chitooligosaccharide elicitors determine the switch from defence involving PAL activation to cell death and water peroxide production in Arabidopsis cell suspensions. Physiol Plant 127:44-56. https://doi.org/10.1111/j.1399-3054.2006.00677.x

Cao Y, Liang Y, Tanaka K, Nguyen CT, Jedrzejczak RP, Joachimiak A, Stacey G (2014) The kinase LYK5 is a major chitin receptor in Arabidopsis and forms a chitin-induced complex with related kinase CERK1. eLife. 3: e03766. https://doi.org/10.7554/eLife.03766

Chae DH, Kim DR, Cheong MS, Lee YB, Kwak YS (2020) Investigating the induced systemic resistance mechanism of 2,4-Diacetylphloroglucinol (DAPG) using DAPG hydrolase-transgenic Arabidopsis. Plant Pathol J 36:255-266. https://doi.org/10.5423/Ppj.Oa.02.2020.0031

Chalfoun NR, Grellet-Bournonville CF, Martinez-Zamora MG, Diaz-Perales A, Castagnaro AP, Diaz-Ricci JC (2013) Purification and characterization of AsES protein a subtilisin secreted by Acremonium strictum is a novel plant defense elicitor. J Biol Chem 288(20):14098-14113. https://doi.org/10.1074/jbc. M112.429423

Chang YH, Yan HZ, Liou RF (2015) A novel elicitor protein from Phytophthora parasitica induces plant basal immunity and systemic acquired resistance. Mol Plant Pathol 16:123-136. https://doi.org/10.1111/mpp.12166

Chen L, Guo X-F, Fan Z-J, Zhang N-L, Zhu Y-J, Zhang Z-M, Khazhieva I, Yurievich MY, Belskaya NP, Bakulev VA (2017) Synthesis and fungicidal activity of 3, 4dichloroisothiazole based strobilurins as potent fungicide candidates. RSC Adv 7:3145-3151

Chen XQ, Mou YH, Ling JH, Wang N, Wang X, Hu JC (2015) Cyclic dipeptides produced by fungus Eupenicillium brefeldianum HMP-F96 induced extracellular alkalinization and $\mathrm{H}_{2} \mathrm{O}_{2}$ production in tobacco cell suspensions. World J Microbiol Biotechnol 31:247-253. https://doi.org/10.1007/s11274-014-1759-0

Chen XR, Li YP, Li QY, Xing YP, Liu BB, Tong YH, Xu JY (2016) SCR96, a small cysteine-rich secretory protein of Phytophthora cactorum, can trigger cell death in the Solanaceae and is important for pathogenicity and oxidative stress tolerance. Mol Plant Pathol 17:577-587. https://doi.org/10.1111/ mpp.12303

Chinchilla D, Shan L, He P, de Vries S, Kemmerling B (2009) One for all: the receptor-associated kinase BAK1. Trends Plant Sci 14:535-541. https://doi. org/10.1016/j.tplants.2009.08.002

Choi HK, Song GC, Yi HS, Ryu CM (2014a) Field evaluation of the bacterial volatile derivative 3-Pentanol in priming for induced resistance in pepper. J Chem Ecol 40(8):882-892. https://doi.org/10.1007/s10886-014-0488-Z

Choi J, Tanaka K, Cao YR, Qi Y, Qiu J, Liang Y, Lee SY, Stacey G (2014b) Identification of a plant receptor for extracellular ATP. Science 343:290-294. https://doi.org/10.1126/science.343.6168.290

Clark G, Fraley D, Steinebrunner I, Cervantes A, Onyirimba J, Liu A, Torres J, Tang WQ, Kim J, Roux SJ (2011) Extracellular nucleotides and apyrases regulate stomatal aperture in Arabidopsis. Plant Physiol 156:1740-1753. https://doi. org/10.1104/pp.111.174466

Crouzet JM, Arguelles-Arias A, Dhondt-Cordelier S, Cordelier S, Prsic J, Hoff G, Mazeyrat-Gourbeyre F, Baillieul F, Clement C, Ongena M, Dorey S (2020) Biosurfactants in plant protection against diseases: Rhamnolipids and Lipopeptides case study. Front Bioeng Biotechnol 8:1014. https://doi.org/1 0.3389/Fbioe.2020.01014

Dangl JL, Horvath DM, Staskawicz BJ (2013) Pivoting the plant immune system from dissection to deployment. Science 341:746-751

de Jonge R, van Esse HP, Maruthachalam K, Bolton MD, Santhanam P, Saber MK, Zhang Z, Usami T, Lievens B, Subbarao KV, Thomma BPHJ (2012) Tomato immune receptor Ve1 recognizes effector of multiple fungal pathogens uncovered by genome and RNA sequencing. Proc Natl Acad Sci U S A 109: 5110-5115. https://doi.org/10.1073/pnas.1119623109

Derevnina L, Dagdas YF, De la Concepcion JC, Bialas A, Kellner R, Petre B, Domazakis E, Du J, Wu CH, Lin X (2016) Nine things to know about elicitins. New Phytol 212:888-895

Dong HS, Delaney TP, Bauer DW, Beer SV (1999) Harpin induces disease resistance in Arabidopsis through the systemic acquired resistance pathway mediated by salicylic acid and the NIM1 gene. Plant J 20:207-215. https:// doi.org/10.1046/j.1365-313x.1999.00595.x

Dow M, Newman MA, von Roepenak E (2000) The induction and modulation of plant defense responses by bacterial lipopolysaccharides. Ann Rev Phytopathol 38:-241. https://doi.org/10.1146/annurev.phyto.38.1.241

Du Q, Yang XD, Zhang JH, Zhong XF, Kim KS, Yang J, Xing GJ, Li XY, Jiang ZY, Li QY, Dong YS, Pan HY (2018) Over-expression of the Pseudomonas syringae harpin-encoding gene hrpZm confers enhanced tolerance to Phytophthora root and stem rot in transgenic soybean. Transgenic Res 27:277-288. https:// doi.org/10.1007/s11248-018-0071-4 
Falcón AB, Cabrera JC, Costales D, Ramírez MA, Cabrera G, Toledo V, MartínezTéllez MA (2008) The effect of size and acetylation degree of chitosan derivatives on tobacco plant protection against Phytophthora parasitica nicotianae. World J Microbiol Biotechnol 24:103

Farzand A, Moosa A, Zubair M, Khan AR, Massawe VC, Tahir HAS, Sheikh TMM, Ayaz M, Gao XW (2019) Suppression of Sclerotinia sclerotiorum by the induction of systemic resistance and regulation of antioxidant pathways in tomato using fengycin produced by Bacillus amyloliquefaciens FZB42. Biomolecules 9:613. https://doi.org/10.3390/Biom9100613

Faulkner C, Petutschnig E, Benitez-Alfonso Y, Beck M, Robatzek S, Lipka V, Maule AJ (2013) LYM2-dependent chitin perception limits molecular flux via plasmodesmata. Proc Natl Acad Sci U S A 110:9166-9170. https://doi.org/10.1 073/pnas. 1203458110

Felix G, Boller T (2003) Molecular sensing of bacteria in plants - the highly conserved RNA-binding motif RNP-1 of bacterial cold shock proteins is recognized as an elicitor signal in tobacco. J Biol Chem 278(8):6201-6208. https://doi.org/10.1074/jbc.M209880200

Felix G, Duran JD, Volko S, Boller T (1999) Plants have a sensitive perception system for the most conserved domain of bacterial flagellin. Plant J 18(3): 265-276. https://doi.org/10.1046/j.1365-313X.1999.00265.x

Fliegmann J, Felix G (2016) IMMUNITY Flagellin seen from all sides. Nat Plants 2(9):16136. https://doi.org/10.1038/Nplants.2016.136

Frias M, Gonzalez M, Gonzalez C, Brito N (2016) BcIEB1, a Botrytis cinerea secreted protein, elicits a defense response in plants. Plant Sci 250:115-124. https:// doi.org/10.1016/j.plantsci.2016.06.009

Fuchs Y, Saxena A, Gamble HR, Anderson JD (1989) Ethylene biosynthesisinducing protein from cellulysin is an endoxylanase. Plant Physiol 89:138143. https://doi.org/10.1104/Pp.89.1.138

Gaulin E, Drame N, Lafitte C, Torto-Alalibo T, Martinez Y, Ameline-Torregrosa C, Khatib M, Mazarguil H, Villalba-Mateos F, Kamoun S, Mazars C, Dumas B, Bottin A, Esquerre-Tugaye MT, Rickauer M (2006) Cellulose binding domains of a Phytophthora cell wall protein are novel pathogen-associated molecular patterns. Plant Cell 18:1766-1777. https://doi.org/10.1105/tpc.105.038687

Gomez-Gomez L, Boller T (2000) FLS2: an LRR receptor-like kinase involved in the perception of the bacterial elicitor flagellin in Arabidopsis. Mol Cell 5:10031011. https://doi.org/10.1016/S1097-2765(00)80265-8

Granado J, Felix G, Boller T (1995) Perception of fungal sterols in plantssubnanomolar concentrations of ergosterol elicit extracellular alkalinization in tomato cells. Plant Physiol 107:485-490. https://doi.org/10.1104/Pp.107.2.485

Gust AA, Biswas R, Lenz HD, Rauhut T, Ranf S, Kemmerling B, Gotz F, Glawischnig E, Lee J, Felix G, Nurnberger T (2007) Bacteria-derived peptidoglycans constitute pathogen-associated molecular patterns triggering innate immunity in Arabidopsis. J Biol Chem 282:32338-32348. https://doi.org/10.1 074/jbc.M704886200

Han Q, Wu FL, Wang XN, Qi H, Shi L, Ren A, Liu QH, Zhao MW, Tang CM (2015) The bacterial lipopeptide iturins induce Verticillium dahliae cell death by affecting fungal signalling pathways and mediate plant defence responses involved in pathogen-associated molecular patterntriggered immunity. Environ Microbiol 17(4):1166-1188. https://doi.org/1 $0.1111 / 1462-2920.12538$

Hander T, Fernandez-Fernandez AD, Kumpf RP, Willems P, Schatowitz $H$, Rombaut D, Staes A, Nolf J, Pottie R, Yao PF, Goncalves A, Pavie B, Boller T, Gevaert K, Van Breusegem F, Bartels S, Stael S (2019) Damage on plants activates $\mathrm{Ca}^{2+}$-dependent metacaspases for release of immunomodulatory peptides. Science 363:1301. https://doi.org/10.1126/science.aar7486

Hayafune M, Berisio R, Marchetti R, Silipo A, Kayama M, Desaki Y, Arima S, Squeglia F, Ruggiero A, Tokuyasu K, Molinaro A, Kaku H, Shibuya N (2014) Chitin-induced activation of immune signaling by the rice receptor CEBiP relies on a unique sandwich-type dimerization. Proc Natl Acad Sci U S A 111: E404-E413. https://doi.org/10.1073/pnas.1312099111

Hiltl C, Siddique S (2020) New allies to fight worms. Nat Plants 6(6):598-599. https://doi.org/10.1038/s41477-020-0699-y

Hong JK, Hwang BK, Kim CH (1999) Induction of local and systemic resistance to Colletotrichum coccodes in pepper plants by dl- $\beta$-amino-n-butyric acid. J Phytopathol 147:193-198

Hou S, Wang X, Chen D, Yang X, Wang M, Turrà D, Di Pietro A, Zhang W (2014) The secreted peptide PIP1 amplifies immunity through receptor-like kinase 7. PLOS Pathog 10(9):e1004331

Houterman PM, Cornelissen BJC, Rep M (2008) Suppression of plant resistance gene-based immunity by a fungal effector. PLoS Pathog 4:e1000061. https://doi.org/10.1371/journal.ppat.1000061
Huffaker A, Pearce G, Ryan CA (2006) An endogenous peptide signal in Arabidopsis activates components of the innate immune response. Proc Natl Acad Sci U S A 103:10098-10103. https://doi.org/10.1073/pnas.0603727103

Jones JD, Dangl JL (2006) The plant immune system. Nature 444(7117):323-329. https://doi.org/10.1038/nature05286

Joseleau J, Cartier N, Chambat G, Faik A, Ruel K (1992) Structural features and biological activity of xyloglucans from suspension-cultured plant cells. Biochimie 74(1):81-88. https://doi.org/10.1016/0300-9084(92)90187-J

Kaku H, Nishizawa Y, Ishii-Minami N, Akimoto-Tomiyama C, Dohmae N, Takio K, Minami E, Shibuya N (2006) Plant cells recognize chitin fragments for defense signaling through a plasma membrane receptor. Proc Natl Acad Sci U S A 103(29):11086-11091. https://doi.org/10.1073/pnas.0508882103

Kano A, Gomi K, Yamasaki-Kokudo Y, Satoh M, Fukumoto T, Ohtani K, Tajima S, Izumori K, Tanaka K, Ishida Y (2010) A rare sugar, D-allose, confers resistance to rice bacterial blight with upregulation of defense-related genes in Oryza sativa. Phytopathology 100(1):85-90. https://doi.org/10.1094/PHYTO-100-10085

Kim MS, Cho SM, Kang EY, Im YJ, Hwangbo H, Kim YC, Ryu C-M, Yang KY, Chung GC, Cho BH (2008) Galactinol is a signaling component of the induced systemic resistance caused by Pseudomonas chlororaphis $\mathrm{O} 6$ root colonization. Mol Plant-Microbe Interact 21:1643-1653

Klarzynski O, Plesse B, Joubert JM, Yvin JC, Kopp M, Kloareg B, Fritig B (2000) Linear beta-1,3 glucans are elicitors of defense responses in tobacco. Plant Physiol 124(3):1027-1038. https://doi.org/10.1104/pp.124.3.1027

Koga J, Yamauchi T, Shimura M, Ogawa N, Oshima K, Umemura K, Kikuchi M, Ogasawara N (1998) Cerebrosides a and C, sphingolipid elicitors of hypersensitive cell death and phytoalexin accumulation in rice plants. J Biol Chem 273:31985-31991. https://doi.org/10.1074/jbc.273.48.31985

Kong HG, Shin TS, Kim TH, Ryu CM (2018) Stereoisomers of the bacterial volatile compound 2,3-butanediol differently elicit systemic defense responses of pepper against multiple viruses in the field. Front Plant Sci 9:90. https://doi. org/10.3389/Fpls.2018.00090

Krol E, Mentzel T, Chinchilla D, Boller T, Felix G, Kemmerling B, Postel S, Arents M, Jeworutzki E, Al-Rasheid KAS, Becker D, Hedrich R (2010) Perception of the Arabidopsis danger signal peptide 1 involves the pattern recognition receptor AtPEPR1 and its close homologue AtPEPR2. J Biol Chem 285(18): 13471-13479. https://doi.org/10.1074/jbc.M109.097394

Kulye M, Liu H, Zhang YL, Zeng HM, Yang XF, Qiu DW (2012) Hrip1, a novel protein elicitor from necrotrophic fungus, Alternaria tenuissima, elicits cell death, expression of defence-related genes and systemic acquired resistance in tobacco. Plant Cell and Environ 35:2104-2120. https://doi.org/10.1111/j.13 65-3040.2012.02539.x

Kumar D, Braun CA, PORTILLO JCT, Ramos ET, RAMIREZ LMC (2018) Use of isotianil for control of zebra chip disease

Kunze G, Zipfel C, Robatzek S, Niehaus K, Boller T, Felix G (2004) The N terminus of bacterial elongation factor Tu elicits innate immunity in Arabidopsis plants. Plant Cell 16:3496-3507. https://doi.org/10.1105/tpc.104.026765

Kutschera A, Dawid C, Gisch N, Schmid C, Raasch L, Gerster T, Schaffer M, Smakowska-Luzan E, Belkhadir Y, Vlot AC, Chandler CE, Schellenberger R, Schwudke D, Ernst RK, Dorey S, Huckelhoven R, Hofmann T, Ranf S (2019) Bacterial medium-chain 3-hydroxy fatty acid metabolites trigger immunity in Arabidopsis plants. Science 364:178-181. https://doi.org/10.1126/science.aa u1279

Lee B, Farag MA, Park HB, Kloepper JW, Lee SH, Ryu CM (2012) Induced resistance by a long-chain bacterial volatile: elicitation of plant systemic defense by a C13 volatile produced by Paenibacillus polymyxa. PLoS ONE 7: e48744. https://doi.org/10.1371/journal.pone.0048744

Lee MW, Huffaker A, Crippen D, Robbins RT, Goggin FL (2018) Plant elicitor peptides promote plant defences against nematodes in soybean. Mol Plant Pathol 19:858-869

Leeman M, denOuden EM, vanPelt JA, Dirkx FPM, Steijl H, Bakker PAHM, Schippers B (1996) Iron availability affects induction of systemic resistance to fusarium wilt of radish by Pseudomonas fluorescens. Phytopathology 86:149155. https://doi.org/10.1094/Phyto-86-149

Li S, Peng X, Wang Y, Hua K, Xing F, Zheng Y, Liu W, Sun W, Wei S (2019) The effector AGLIP1 in Rhizoctonia solani AG1 IA triggers cell death in plants and promotes disease development through inhibiting PAMP-triggered immunity in Arabidopsis thaliana. Front Microbiol 10:2228. https://doi.org/10.3389/ fmicb.2019.02228

Li WQ, Shao M, Zhong WG, Yang J, Okada K, Yamane H, Zhang L, Wang G, Wang D, Xiao SS, Chang SS, Qian GL, Liu FQ (2012) Ectopic expression of Hrf1 
enhances bacterial resistance via regulation of diterpene phytoalexins, silicon and reactive oxygen species burst in rice. PLoS ONE 7:e43914. https://doi. org/10.1371/journal.pone.0043914

Liang XX, Zhou JM (2018) Receptor-like cytoplasmic kinases: central players in plant receptor kinase-mediated signaling. Annu Rev Plant Biol 69:267-299. https://doi.org/10.1146/annurev-arplant-042817-040540

Liu B, Li JF, Ao Y, Qu JW, Li ZQ, Su JB, Zhang Y, Liu J, Feng DR, Qi KB, He YM, Wang JF, Wang HB (2012a) Lysin motif-containing proteins LYP4 and LYP6 play dual roles in peptidoglycan and chitin perception in rice innate immunity. Plant Cell 24:3406-3419. https://doi.org/10.1105/tpc.112.102475

Liu ZH, Zhang ZC, Faris JD, Oliver RP, Syme R, McDonald MC, McDonald BA Solomon PS, Lu SW, Shelver WL, Xu S, Friesen TL (2012b) The cysteine rich necrotrophic effector SnTox1 produced by Stagonospora nodorum triggers susceptibility of wheat lines harboring Snn1. PLoS Pathog 8:e1002467. https://doi.org/10.1371/journal.ppat.1002467

Lozano-Torres JL, Wilbers RHP, Gawronski P, Boshoven JC, Finkers-Tomczak A, Cordewener JHG, America AHP, Overmars HA, Van't Klooster JW, Baranowski L, Sobczak M, llyas M, RAL V d H, Schots A, PJGM d W, Bakker J, Goverse A, Smant G (2012) Dual disease resistance mediated by the immune receptor $\mathrm{Cf}-2$ in tomato requires a common virulence target of a fungus and a nematode. Proc Natl Acad Sci U S A 109:10119-10124. https://doi.org/10.1 073/pnas.1202867109

Lu C, Liu H, Jiang D, Wang L, Jiang Y, Tang S, Hou X, Han X, Liu Z, Zhang M (2019) Paecilomyces variotii extracts (ZNC) enhance plant immunity and promote plant growth. Plant Soil 441:383-397

Ma Y, Han C, Chen J, Li H, He K, Liu A, Li D (2015a) Fungal cellulase is an elicitor but its enzymatic activity is not required for its elicitor activity. Mol Plant Pathol 16:14-26

Ma ZC, Song TQ, Zhu L, Ye WW, Wang Y, Shao YY, Dong SM, Zhang ZG, Dou DL, Zheng XB, Tyler BM, Wang YC (2015b) A Phytophthora sojae glycoside hydrolase 12 protein is a major virulence factor during soybean infection and is recognized as a PAMP. Plant Cell 27:2057-2072. https://doi.org/10.1105/ tpc. 15.00390

Ma ZC, Zhu L, Song TQ, Wang Y, Zhang Q, Xia YQ, Qiu M, Lin YC, Li HY, Kong L, Fang YF, Ye WW, Wang Y, Dong SM, Zheng XB, Tyler BM, Wang YC (2017) A paralogous decoy protects Phytophthora sojae apoplastic effector PSXEG1 from a host inhibitor. Science 355:710-714. https://doi.org/10.1126/science.aai7919

Ménard R, Alban S, de Ruffray P, Jamois F, Franz G, Fritig B, Yvin J-C, Kauffmann S (2004) $\beta-1,3$ glucan sulfate, but not $\beta-1,3$ glucan, induces the salicylic acid signaling pathway in tobacco and Arabidopsis. Plant Cell 16(11):3020-3032. https://doi.org/10.1105/tpc.104.024968

Návarová H, Bernsdorff F, Döring A-C, Zeier J (2012) Pipecolic acid, an endogenous mediator of defense amplification and priming, is a critical regulator of inducible plant immunity. Plant Cell 24(12):5123-5141. https:// doi.org/10.1105/tpc.112.103564

Nie J, Yin Z, Li Z, Wu Y, Huang L (2019) A small cysteine-rich protein from two kingdoms of microbes is recognized as a novel pathogen-associated molecular pattern. New Phytol 222:995-1011

Nurnberger T, Nennstiel D, Jabs T, Sacks WR, Hahlbrock K, Scheel D (1994) Highaffinity binding of a fungal oligopeptide elicitor to parsley plasmamembranes triggers multiple defense responses. Cell 78:449-460. https://doi. org/10.1016/0092-8674(94)90423-5

Oerke EC, Dehne HW (2004) Safeguarding production-losses in major crops and the role of crop protection. Crop Prot 23:275-285

Ökmen B, Bachmann D, De Wit PJ (2019) A conserved GH17 glycosyl hydrolase from plant pathogenic Dothideomycetes releases a DAMP causing cell death in tomato. Mol Plant Pathol 20:1710-1721

Omoboye OO, Oni FE, Batool H, Yimer HZ, De Mot R, Hofte M (2019) Pseudomonas cyclic lipopeptides suppress the rice blast fungus Magnaporthe oryzae by induced resistance and direct antagonism. Front Plant Sci 10:901. https://doi.org/10.3389/Fpls.2019.00901

Oome S, Raaymakers TM, Cabral A, Samwel S, Bohm H, Albert I, Nurnberger T, Van den Ackerveken G (2014) Nep1-like proteins from three kingdoms of life act as a microbe-associated molecular pattern in Arabidopsis. Proc Natl Acad Sci U S A 111(47):16955-16960. https://doi.org/10.1073/pnas.1410031111

Oostendorp M, Kunz W, Dietrich B, Staub T (2001) Induced disease resistance in plants by chemicals. Eur J Plant Pathol 107:19-28

Orsomando G, Lorenzi M, Raffaelli N, Dalla Rizza M, Mezzetti B, Ruggieri S (2001) Phytotoxic protein PCF: purification, characterization, and cDNA sequencing of a novel hydroxyproline-containing factor secreted by the strawberry pathogen Phytophthora cactorum. J Biol Chem 276:21578-21584
Ozeretskovskaya O, Vasyukova N, Panina YS, Chalenko G (2006) Effect of immunomodulators on potato resistance and susceptibility to Phytophthora infestans. Russ J Plant Physiol 53(4):488-494. https://doi.org/10.1134/S1021443 706040091

Pavli Ol, Kelaidi Gl, Tampakaki AP, Skaracis GN (2011) The hrpZ gene of Pseudomonas syringae pv. Phaseolicola enhances resistance to Rhizomania disease in transgenic Nicotiana benthamiana and sugar beet. PLoS ONE 6: e17306. https://doi.org/10.1371/journal.pone.0017306

Pearce G, Moura DS, Stratmann J, Ryan CA (2001) RALF, a 5-kDa ubiquitous polypeptide in plants, arrests root growth and development. Proc Natl Acad Sci 98:12843-12847

Pearce G, Strydom D, Johnson S, Ryan CA (1991) A polypeptide from tomato leaves induces wound-inducible proteinase-inhibitor proteins. Science 253 : 895-898. https://doi.org/10.1126/science.253.5022.895

Pearce G, Yamaguchi Y, Barona G, Ryan CA (2010) A subtilisin-like protein from soybean contains an embedded, cryptic signal that activates defense-related genes. Proc Natl Acad Sci U S A 107:14921-14925. https://doi.org/10.1073/ pnas.1007568107

Peng DH, Qiu DW, Ruan LF, Zhou CF, Sun M (2011) Protein elicitor PemG1 from Magnaporthe grisea induces systemic acquired resistance (SAR) in plants. Mol Plant-Microbe Interact 24:1239-1246. https://doi.org/10.1094/Mpmi-01-11-0003

Petutschnig EK, Jones AME, Serazetdinova L, Lipka U, Lipka V (2010) The lysin motif receptor-like kinase (LysM-RLK) CERK1 is a major chitin-binding protein in Arabidopsis thaliana and subject to chitin-induced phosphorylation. J Biol Chem 285:28902-28911. https://doi.org/10.1074/jbc.M110.116657

Poinssot B, Vandelle E, Bentejac M, Adrian M, Levis C, Brygoo Y, Garin J, Sicilia F, Coutos-Thevenot P, Pugin A (2003) The endopolygalacturonase 1 from Botrytis cinerea activates grapevine defense reactions unrelated to its enzymatic activity. Mol Plant-Microbe Interact 16:553-564. https://doi.org/1 0.1094/Mpmi.2003.16.6.553

Qian ZG, Zhao ZJ, Xu Y, Qian X, Zhong JJ (2006) Novel chemically synthesized salicylate derivative as an effective elicitor for inducing the biosynthesis of plant secondary metabolites. Biotechnol Prog 22:331-333

Qiu DW (2016) Research status and trend analysis of plant immune induction technology in China. Plant Prot 42:10-14

Qiu DW, Dong YJ, Zhang Y, Li SP, Shi FC (2017) Plant immunity inducer development and application. Mol Plant-Microbe Interact 30(5):355-360. https://doi.org/10.1094/Mpmi-11-16-0231-Cr

Qutob D, Kamoun S, Gijzen M (2002) Expression of a Phytophthora sojae necrosisinducing protein occurs during transition from biotrophy to necrotrophy. Plant J 32:361-373. https://doi.org/10.1046/j.1365-313X.2002.01439.x

Rahman A, Uddin W, Wenner NG (2015) Induced systemic resistance responses in perennial ryegrass against Magnaporthe oryzae elicited by semi-purified surfactin lipopeptides and live cells of Bacillus amyloliquefaciens. Mol Plant Pathol 16:546-558. https://doi.org/10.1111/mpp.12209

Reignault P, Cogan A, Muchembled J, Sahraoui ALH, Durand R, Sancholle M (2001) Trehalose induces resistance to powdery mildew in wheat. New Phytol 149(3):519-529. https://doi.org/10.1046/j.1469-8137.2001.00035.x

Rep M, van der Does HC, Meijer M, van Wijk R, Houterman PM, Dekker HL, de Koster CG, Cornelissen BJC (2004) A small, cysteine-rich protein secreted by fusarium oxysporum during colonization of xylem vessels is required for I-3mediated resistance in tomato. Mol Microbiol 53:1373-1383. https://doi.org/1 0.1111/j.1365-2958.2004.04177.x

Ricci P, Bonnet P, Huet JC, Sallantin M, Beauvaiscante F, Bruneteau M, Billard V, Michel G, Pernollet JC (1989) Structure and activity of proteins from pathogenic fungi Phytophthora eliciting necrosis and acquired-resistance in tobacco. Eur J Biochem 183:555-563. https://doi.org/10.1111/j.1432-1033.1 989.tb21084.x

Rohe M, Gierlich A, Hermann H, Hahn M, Schmidt B, Rosahl S, Knogge W (1995) The race-specific elicitor, Nip1, from the barley pathogen, Rhynchosporium Secalis, determines avirulence on host plants of the Rrs1 resistance genotype. EMBO J 14:4168-4177

Romeiro RS, Kimura O (1997) Induced resistance in pepper leaves infiltrated with purified bacterial elicitors from Xanthomonas campestris pv. Vesicatoria. J Phytopathol 145:495-498. https://doi.org/10.1111/j.1439-0434.1997.tb00356.x

Sanchez L, Courteaux B, Hubert J, Kauffmann S, Renault JH, Clement C, Baillieul F, Dorey S (2012) Rhamnolipids elicit defense responses and induce disease resistance against biotrophic, hemibiotrophic, and necrotrophic pathogens that require different signaling pathways in Arabidopsis and highlight a central role for salicylic acid. Plant Physiol 160:1630-1641. https://doi.org/1 $0.1104 /$ pp.112.201913 
Savchenko T, Walley JW, Chehab EW, Xiao YM, Kaspi R, Pye MF, Mohamed ME, Lazarus CM, Bostock RM, Dehesh K (2010) Arachidonic acid: an evolutionarily conserved signaling molecule modulates plant stress signaling networks. Plant Cell 22:3193-3205. https://doi.org/10.1105/tpc.110.073858

Schmelz EA, Carroll MJ, LeClere S, Phipps SM, Meredith J, Chourey PS, Alborn HT, Teal PE (2006) Fragments of ATP synthase mediate plant perception of insect attack. Proc Natl Acad Sci 103:8894-8899

Schuhegger R, Ihring A, Gantner S, Bahnweg G, Knappe C, Vogg G, Hutzler P, Schmid M, Van Breusegem F, Eberl L, Hartmann A, Langebartels C (2006) Induction of systemic resistance in tomato by $\mathrm{N}$-acyl-L-homoserine lactoneproducing rhizosphere bacteria. Plant Cell Environ 29:909-918. https://doi. org/10.1111/j.1365-3040.2005.01471.x

Schwessinger B, Ronald PC (2012) Plant innate immunity: perception of conserved microbial signatures. Annu Rev Plant Biol 63(1):451-482. https:// doi.org/10.1146/annurev-arplant-042811-105518

Sharp JK, Valent B, Albersheim P (1984) Purification and partial characterization of a beta-glucan fragment that elicits phytoalexin accumulation in soybean. J Biol Chem 259:11312-11320

Shcherbakova LA, Odintsova TI, Stakheev AA, Fravel DR, Zavriev SK (2016) Identification of a novel small cysteine-rich protein in the fraction from the biocontrol fusarium oxysporum strain CS-20 that mitigates fusarium wilt symptoms and triggers defense responses in tomato. Front Plant Sci 6:1207. https://doi.org/10.3389/Fpls.2015.01207

Shen YR, Li JW, Xiang JL, Wang JQ, Yin KD, Liu Q (2019) Isolation and identification of a novel protein elicitor from a Bacillus subtilis strain BU412. AMB Express 9:117. https://doi.org/10.1186/S13568-019-0822-5

Shiu SH, Bleecker AB (2003) Expansion of the receptor-like kinase/Pelle gene family and receptor-like proteins in Arabidopsis. Plant Physiol 132:530-543. https://doi.org/10.1104/pp.103.021964

Shiu SH, Karlowski WM, Pan RS, Tzeng YH, Mayer KFX, Li WH (2004) Comparative analysis of the receptor-like kinase family in Arabidopsis and rice. Plant Cell 16:1220-1234. https://doi.org/10.1105/Tpc.020834

Stübler D, Buchenauer H (1996) Antiviral activity of the glucan lichenan (poly- $\beta$ $(I \rightarrow 3,1 \rightarrow 4)$ D-anhydroglucose) biological activity in tobacco plants. J Phytopathol 144(1):37-43. https://doi.org/10.1111/j.1439-0434.1996.tb01486.x

Sun FQ, Li JQ, Qi JS, Gao LH (2016) Effect of foliar spraying Verticillium dahiliae allergen asp f2-like (VdAL) during seedling stage on storage quality of commercial cucumber seedlings. China Vegetables 3:48-52

Tanaka K, Choi JM, Cao YR, Liang Y, Qi Y, Qiu J, Stacey G (2014) Identification of a plant receptor for extracellular ATP. Science 343:290-294. https://doi.org/1 $0.1126 /$ science.343.6168.290

Tang DZ, Wang GX, Zhou JM (2017) Receptor kinases in plant-pathogen interactions: more than pattern recognition. Plant Cell 29:618-637. https:// doi.org/10.1105/tpc.16.00891

ten Have A, Mulder W, Visser J, van Kan JAL (1998) The endopolygalacturonase gene Bcpg1 is required for full virulence of Botrytis cinerea. Mol PlantMicrobe Interact 11:1009-1016

Thakur M, Sohal BS (2013) Role of elicitors in inducing resistance in plants against pathogen infection: a review. ISRN biochemistry 2013

Thynne E, Saur IML, Simbaqueba J, Ogilvie HA, Gonzalez-Cendales Y, Mead O, Taranto A, Catanzariti AM, McDonald MC, Schwessinger B, Jones DA, Rathjen JP, Solomon PS (2017) Fungal phytopathogens encode functional homologues of plant rapid alkalinization factor (RALF) peptides. Mol Plant Pathol 18(6):811-824. https://doi.org/10.1111/mpp.12444

van Dijl JM, Hecker M (2013) Bacillus subtilis: from soil bacterium to supersecreting cell factory. Microb Cell Factories 12(1):3. https://doi.org/10.1186/14 75-2859-12-3

Wang BN, Yang XF, Zeng HM, Liu H, Zhou TT, Tan BB, Yuan JJ, Guo LH, Qiu DW (2012a) The purification and characterization of a novel hypersensitive-like response-inducing elicitor from Verticillium dahliae that induces resistance responses in tobacco. Appl Microbiol Biotechnol 93:191-201. https://doi. org/10.1007/s00253-011-3405-1

Wang C, Huang X, Li Q, Zhang Y, Li J-L, Mou Z (2019a) Extracellular pyridine nucleotides trigger plant systemic immunity through a lectin receptor kinase/BAK1 complex. Nat Commun 10:1-16

Wang H, Yang X, Guo L, Zeng H, Qiu D (2015) PeBL1, a novel protein elicitor from Brevibacillus laterosporus strain A60, activates defense responses and systemic resistance in Nicotiana benthamiana. Appl Environ Microbiol 81(8): 2706-2716. https://doi.org/10.1128/AEM.03586-14

Wang SS, Xing RK, Wang Y, Shu HD, Fu SG, Huang J, Paulus JK, Schuster M, Saunders DGO, Win J, Vleeshouwers V, Wang YC, Zheng XB, van der Hoorn
RAL, Dong SM (2021) Cleavage of a pathogen apoplastic protein by plant subtilases activates host immunity. New Phytol 229. https://doi.org/10.1111/ nph. 17120

Wang W, Zhou P, Mo X, Hu L, Jin N, Chen X, Yu Z, Meng J, Erb M, Shang Z (2020) Induction of defense in cereals by 4 -fluorophenoxyacetic acid suppresses insect pest populations and increases crop yields in the field. Proc Natl Acad Sci 117:12017-12028. https://doi.org/10.1073/pnas.2003742117

Wang X, Wang X, Feng H, Tang C, Bai P, Wei G, Huang L, Kang Z (2012b) TaMCA4, a novel wheat metacaspase gene functions in programmed cell death induced by the fungal pathogen Puccinia striiformis f. sp. tritici. Mol Plant-Microbe Interact 25:755-764

Wang Y, Luo W, Huang Y, Xu L, Yin Y (2017) Improved control of clubroot (Plasmodiophora brassicae) by a mixture of a fungicide and a plant defense inducer. J Plant Dis Prot 124:67-71

Wang Y, Tyler BM, Wang Y (2019b) Defense and counterdefense during plantpathogenic oomycete infection. Annu Rev Microbiol 73:667-696

Wang Y, Xu YP, Sun YJ, Wang HB, Qi JM, Wan BW, Ye WW, Lin YC, Shao YY, Dong SM, Tyler BM, Wang YC (2018) Leucine-rich repeat receptor-like gene screen reveals that Nicotiana RXEG1 regulates glycoside hydrolase 12 MAMP detection. Nat Commun 9:594. https://doi.org/10.1038/s41467-018-03010-8

Wang YC, Hu DW, Zhang ZG, Ma ZC, Zheng XB, Li DB (2003) Purification and immunocytolocalization of a novel Phytophthora boehmeriae protein inducing the hypersensitive response and systemic acquired resistance in tobacco and Chinese cabbage. Physiol Mol Plant Pathol 63(4):223-232. https://doi.org/10.1016/j.pmpp.2003.12.004

Watt SA, Tellstrom V, Patschkowski T, Niehaus K (2006) Identification of the bacterial superoxide dismutase (SodM) as plant-inducible elicitor of an oxidative burst reaction in tobacco cell suspension cultures. J Biotechnol 126 78-86. https://doi.org/10.1016/j.jbiotec.2006.02.022

Wei ZM, Laby RJ, Zumoff CH, Bauer DW, He SY, Collmer A, Beer SV (1992) Harpin, elicitor of the hypersensitive response produced by the plant pathogen Erwinia Amylovora. Science 257:85-88. https://doi.org/10.1126/science.1621 099

Wu HJ, Wang SA, Qiao JQ, Liu J, Zhan J, Gao XW (2009) Expression of HpaG (Xooc) protein in Bacillus subtilis and its biological functions. J Microbiol Biotechnol 19:194-203. https://doi.org/10.4014/jmb.0802.154

Xu YP, Zhang YH, Zhu J, Y, Sun YJ, Guo BD, Liu F, Huang J, Wang HN, Dong SM, Wang Y, Wang YC (2021) Phytophthora sojae apoplastic effector AEP1 mediates sugar uptake by mutarotation of extracellular aldose and is recognized as a MAMP. Plant Physiol https://doi.org/10.1093/plphys/kiab239

Yamaguchi Y, Barona G, Ryan CA, Pearce G (2011) GmPep914, an eight-amino acid peptide isolated from soybean leaves, activates defense-related genes. Plant Physiol 156(2):932-942. https://doi.org/10.1104/pp.111.173096

Yamaguchi Y, Huffaker A, Bryan AC, Tax FE, Ryan CA (2010) PEPR2 is a second receptor for the Pep1 and Pep2 peptides and contributes to defense responses in Arabidopsis. Plant Cell 22:508-522. https://doi.org/10.1105/tpc.109.068874

Yang B, Wang YY, Tian MJ, Dai KX, Zheng WY, Liu ZH, Yang S, Liu XY, Shi DY, Zhang HF, Wang Y, Ye WW, Wang YC (2021) Fg12 ribonuclease secretion contributes to fusarium graminearum virulence and induces plant cell death. J Integr Plant Biol 63:365-377. https://doi.org/10.1111/jipb.12997

Yang Y, Zhang H, Li G, Li W, Wang X, Song F (2009) Ectopic expression of MgSM1, a Cerato-platanin family protein from Magnaporthe grisea, confers broad-spectrum disease resistance in Arabidopsis. Plant Biotechnol J 7(8): 763-777. https://doi.org/10.1111/j.1467-7652.2009.00442.x

Yang Y, Zhang Y, Li B, Yang X, Dong Y, Qiu D (2018) A Verticillium dahliae pectate lyase induces plant immune responses and contributes to virulence. Front Plant Sci 9:1271

Yoshioka K, Nakashita H, Klessig DF, Yamaguchi I (2001) Probenazole induces systemic acquired resistance in Arabidopsis with a novel type of action. Plant J 25(2):149-157. https://doi.org/10.1046/j.1365-313x.2001.00952.x

Zang H, Xie S, Zhu B, Yang X, Gu C, Hu B, Gao T, Chen Y, Gao X (2019) Mannan oligosaccharides trigger multiple defence responses in rice and tobacco as a novel danger-associated molecular pattern. Mol Plant Pathol 20(8):10671079. https://doi.org/10.1111/mpp.12811

Zhang H, Hu Z, Lei C, Zheng C, Wang J, Shao S, Li X, Xia X, Cai X, Zhou J (2018a) A plant phytosulfokine peptide initiates auxin-dependent immunity through cytosolic Ca2+ signaling in tomato. Plant Cell 30:652-667

Zhang HJ, Wu Q, Cao S, Zhao TY, Chen L, Zhuang PT, Zhou XH, Gao ZM (2014a) A novel protein elicitor (SsCut) from Sclerotinia sclerotiorum induces multiple defense responses in plants. Plant Mol Biol 86(4-5):495-511. https://doi.org/1 $0.1007 /$ s11103-014-0244-3 
Zhang L, Gleason C (2020) Enhancing potato resistance against root-knot nematodes using a plant-defence elicitor delivered by bacteria. Nat Plants 6: 625-629. https://doi.org/10.1038/s41477-020-0689-0

Zhang LS, Kars I, Essenstam B, Liebrand TWH, Wagemakers L, Elberse J, Tagkalaki $P$, Tjoitang D, van den Ackerveken G, van Kan JAL (2014b) Fungal endopolygalacturonases are recognized as microbe-associated molecular patterns by the Arabidopsis receptor-like protein RESPONSIVENESS TO BOTRYTIS POLYGALACTURONASES1. Plant Physiol 164:352-364. https://doi. org/10.1104/pp.113.230698

Zhang Y, Gao Y, Liang Y, Dong Y, Yang X, Yuan J, Qiu D (2017) The Verticillium dahliae SnodProt1-like protein VdCP1 contributes to virulence and triggers the plant immune system. Front Plant Sci 8:1880

Zhang Y, Yan X, Guo H, Zhao F, Huang L (2018b) A novel protein elicitor BAR11 from Saccharothrix yanglingensis Hhs.015 improves plant resistance to pathogens and interacts with catalases as targets. Frontiers in. Microbiology 9:700

Zhang Y, Zhang YH, Qiu DW, Zeng HM, Guo LH, Yang XF (2015) BcGs1, a glycoprotein from Botrytis cinerea, elicits defence response and improves disease resistance in host plants. Biochem Biophys Res Commun 457:627634. https://doi.org/10.1016/j.bbrc.2015.01.038

Zhang YH, Yang XF, Zeng HM, Guo LH, Yuan JJ, Qiu DW (2014c) Fungal elicitor protein PebC1 from Botrytis cinerea improves disease resistance in Arabidopsis thaliana. Biotechnol Lett 36:1069-1078. https://doi.org/10.1007/s1 0529-014-1462-0

Zhou JM, Zhang YL (2020) Plant immunity: danger perception and signaling. Cell 181:978-989. https://doi.org/10.1016/j.cell.2020.04.028

Zhou M, Wang W (2018) Recent advances in synthetic chemical inducers of plant immunity. Front Plant Sci 9:1613

Zipfel C (2014) Plant pattern-recognition receptors. Trends Immunol 35:345-351

Zipfel C, Kunze G, Chinchilla D, Caniard A, Jones JDG, Boller T, Felix G (2006)

Perception of the bacterial PAMP EF-Tu by the receptor EFR restricts Agrobacterium-mediated transformation. Cell 125:749-760. https://doi.org/1 0.1016/j.cell.2006.03.037

\section{Publisher's Note}

Springer Nature remains neutral with regard to jurisdictional claims in published maps and institutional affiliations. 